\title{
Layanan Bimbingan Klasikal Dampak Phubbing pada Siswa Kelas VII SMP Negeri 25 Banjarmasin
}

\author{
Ali Rachman ${ }^{1}$, Muhammad Andri Setiawan², Jessica Ester Bawimbang², \\ Faisal Rachman ${ }^{3}$ \\ 1, 2 Universitas Lambung Mangkurat, ${ }^{3}$ SMP Negeri 25 Banjarmasin
}

\begin{abstract}
Article History ABSTRACT
Received 24.06.2019

Received in revised form

01.10 .2019

Accepted 05.10.2019

Available online 28.10.2019

CLASSICAL GUIDANCE SERVICES IMPACT PHUBBING IN CLASS VII

STUDENTS OF SMP NEGERI 25 BANJARMASIN. Millennial generation is inseparable from the use of smart phones as the latest communication technology media. The negative impact that is felt from the development of smart phones is the birth of phubbing behavior which means the act of ignoring others when interacting with social communication with more focus on paying attention to cellphones. Departing from these problems, it is necessary to provide classical guidance services on the effects of phubbing. What was done in SMPN 25 Banjarmasin was based on the request of partners, namely the SMPN 25 Banjarmasin guidance teacher based on the results of developing practical conditional information in the field. Implementation of classical guidance services. To find out the description of phubbing behavior in class VII students, the Generic Scale of Phubbing (GSP) instrument is used before and after service delivery. The results of the implementation of the service showed that this classical guidance service was successful in reducing students becoming phubbing actors. It is suggested that the implementation of classical guidance services can be a preliminary study for phubbing research.
\end{abstract}

KEYWORDS: Classical Guidance Service, Phubbing, Students.

DOI: $10.30653 / 002.201943 .156$

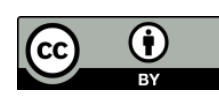

This is an open access article distributed under the terms of the Creative Commons Attribution 4.0 International License, which permits unrestricted use, distribution, and reproduction in any medium, provided the original work is properly cited. ๑ 2019 Ali Rachman, Muhammad Andri Setiawan, Jessica Ester Bawimbang, Faisal Rachman.

\section{PENDAHULUAN}

Perkembangan massif teknologi ponsel cerdas dari permulaan tahun 2000-an semakin menekankan penyederhanaan dalam berkomunikasi dan berinteraksi sosial. Orang berpikir untuk tumbuh dan berkembang inovatif secara instan dan praktis. Pada ranah ini maka teknologi ponsel cerdas dianggap mampu menjawab tantangan tersebut. Apalagi para produser ponsel cerdas berlomba-lomba mengembangkan terobosan

${ }^{1}$ Corresponding author: Program Studi Bimbingan dan Konseling, FKIP Universitas Lambung Mangkurat; Jl. Brigjen H. Hasan Basri, Banjarmasin, Kalimantan Selatan; Email: andri.bk@ulm.ac.id 
inovasi teknologi yang diharapkan dapat menjawab kebutuhan masyarakat modern yang dinamis. Jadilah, ponsel yang selama ini hanya dipergunakan untuk kebutuhan mendasar hanya untuk menelopon dan memberi pesan singkat, menjadi 'jendela komunikasi' baru cara manusia berkomunikasi.

Pola interaksi sosial yang menimpa pelaku kecanduan ponsel pintar berubah dengan drastis seperti dalam menunjukkan image diri atau mempresentasikan diri karena sekilas terlihat media sosial memberikan ruang bagi setiap individu berkreasi, khususnya dalam menampilkan diri seperti menuliskan kata-kata bijak di status maupun tweets, menyampaikan kritik, mengkomunikasikan kondisi pribadi, menyampaikan aktivitas dan lokasi, dan berbagai cara lainnya. Hanya saja presentasi diri yang mereka rancang bisa saja semu dan tidak menunjukkan jati diri mereka yang sebenarnya, karena yang mereka tampilkan hanyalah topeng untuk menunjukan keadaan yang sebenarnya. Jelas sikap ini menunjukkan hubungan interaksi sosial yang tidak sehat dengan bermuara pada sikap ketidakhati-hatian bersikap (Luik, 2011).

Senada dengan penjelasan di atas Sherry Turkle dari Massachusetts Institute of Technology mengungkapkan bahwa ketergantungan pada ponsel bisa membunuh rasa empati pada diri manusia dan implikasi luasnya juga merusak budaya, keluarga dan kesehatan mental, secara statistik menunjukkan 89\% orang Amerika mengakui mereka lebih banyak menggunakan ponsel untuk bersosialisasi dengan orang lain, terutama anak-anak dan remaja yang berakibat kehilangan empati yang secara jangka panjang bisa menyebabkan cyber bullying (Al Subaihi, 2017).

Bahaya inilah yang kemudian diistilahkan sebagai phubbing, Spiegelhalther (Ramadhani \& Rezkisari, 2016) mengatakan jutaan pria dan wanita zaman sekarang begitu kecanduan teknologi, seperti mengirim pesan teks, email, mengirim tweet, mengunggah foto di Instagram, atau memperbaharui status di laman Facebook. Ini dikenal dengan sebutan 'phubbing' atau 'phone and snubbing.' Mereka memperlakukan ponsel layaknya keluarga, teman, sahabat, bahkan pasangan. Phubbing menyebar luas di seluruh dunia. Hubungan sosial terjalin berdasarkan update status. Kemampuan berbicara atau berkomunikasi tatap muka benar-benar hilang sehingga lambat laun mereka tak lagi bisa memisahkan kehidupan pribadi dengan sosial dan semuanya bercampur dan bisa diketahui publik.

Berdasarkan berbagai uraian di atas, jelas kondisi ini secara langsung dialami generasi muda (remaja) yang notebene-nya rata-rata siswa sekolah menangah. Mereka adalah generasi $Z$ yang dalam rentang kelahiran tahun 1995 sampai dengan tahun 2010. Hampir semua waktu yang dimiliki oleh remaja generasi $Z$ dihabiskan untuk World Wide Web. Generasi $\mathrm{Z}$ terbiasa berteman dengan orang banyak melalui media sosial. Namun, mereka tidak terlalu memiliki kecakapan yang baik untuk bersosialisasi secara langsung (Youarti \& Hidayah, 2018, pp. 148-149).

Berangkat dari permasalahan di atas maka, maka diperlukan pemberian layanan bimbingan klasikal dampak phubbing terhadap siswa sekolah menengah khususnya siswa SMP (Sekolah Menengah Pertama) tentang dampak yang ditimbulkan oleh perilaku phubbing dengan mengambil tempat di SMP Negeri 25 Banjarmasin, karena berdasarkan hasil pengembangan informasi kondisional praktis bersama guru BK yakni SMP Negeri 25 Banjarmasin terindikasi sejumlah siswa sebagai perilaku phubbing. 


\section{METODE PELAKSANAAN}

Sebagaimana dikemukakan di atas kegiatan pengabdian kepada kepada masyarakat dilakukan di SMP Negeri 25 Banjarmasin, Kecamatan Banjarmasin Barat, Kota Banjarmasin. Sasarannya adalah siswa kelas VII. Secara umum kegiatan ini menggunakan jenis layanan bimbingan klasikal dengan pelaksanaan seperti yang disusun oleh Tim Penyusun Panduan Operasional Penyelenggaraan Bimbingan dan Konseling (2016).

Bimbingan klasikal itu sendiri merupakan kegiatan layanan yang diberikan kepada sejumlah siswa dalam satu rombongan belajar dan dilaksanakan di kelas dalam bentuk tatap muka dengana guru bimbingan dan konseling atau konselor. Metode bimbingan klasikal antara lain diskusi, bermain peran, dan ekspositori. Bimbingan klasikal merupakan salah satu strategi layanan dasar serta layanan peminatan dan perencanaan indivual pada komponen program bimbingan dan konseling. Bimbingan klasikal diberikan kepada semua siswa/konseli dan bersifat pengembangan, pencegahan, dan pemeliharaan (Tim Penyusun Panduan Operasional Penyelenggaraan Bimbingan dan Konseling, 2016)

Layanan bimbingan klasikal berupa pemaparan mengenai dampak phubbing bagi siswa. Pelaksanaan layanan bimbingan klasikal diawali dengan pre-test dan selanjutnya pada akhir paparan diberikan post-test menggunakan instrumen Generic Scale of Phubbing (GSP) yang disusun oleh Chotpitayasunondh \& Douglas (2018) dan diterjemahkan dalam bahasa Indonesia dari bahasa Inggris dengan bantuan dosen pendidikan bahasa Inggris. Tim membagikan instrumen tersebut untuk diisi. Data kuesioner dan hasil pre-test dan post-test selanjutnya dianalisis secara sederhana.

Pada kegiatan ini, tim menggunakan beberapa metode untuk menginformasikan dampak phubbing kepada siswa kelas VII dengan harapan supaya tujuan kegiatan ini dapat tercapai. Metode ceramah digunakan oleh tim untuk menyampaikan informasi mengenai dampak phubbing berdasarkan hasil riset yang terbaru dengan bahasa sederhana. Selanjutnya melalui metode diskusi, siswa dipersilahkan untuk menceritakan permasalahan dan pengalaman phubbing yang mereka alami baik sebagai pelaku maupun korban. Pada metode ini tim memperlihatkan video berdurasi pendek tentang bahaya dan dampak phubbing kemudian tim memberikan kesempatan kepada siswa untuk bertanya mengenai segala hal terkait bahaya phubbing.

\section{HASIL DAN PEMBAHASAN}

Pelaksanaan Pengabdian kepada Masyarakat (PkM) ini merupakan hasil kolaborasi antara Program Studi Bimbingan dan Konseling FKIP Universitas Lambung Mangkurat dengan guru BK (Bimbingan dan Konseling) SMP Negeri 25 Banjarmasin. Pelaksanaan PkM ini dimulai ketika Guru Bimbingan dan Konseling SMP Negeri 25 Banjarmasin berkonsultasi informasikan sejumlah siswa diduga menjadi pelaku phubbing.

Berdasarkan apa yang disampaikan oleh guru BK maka Tim Pengabdian kepada Masyarakat kemudian meminta guru Bimbingan dan Konseling untuk mengindentifikasikan siswa yang diduga pelaku phubbing tersebut dengan melakukan observasi secara intensif selama bulan Mei berdasarkan pandangan Reid (2018: 183-184) phubber (pelaku phubbing) menunjukkan sejumlah gejala diantaranya: pertama, setiap saat selalu dekat dengan ponsel, dan tidak bisa jauh-jauh darinya. Kedua, berinteraksi verbal 
dengan orang lain berdurasi sebentar, karena perhatian lebih terfokus pada perangkat smartphone masing-masing. Ketiga, menggunakan ponsel sebagai selingan untuk menghindari pekerjaan atau tugas sehari-hari. Keempat, jika menonton TV, lebih memeriksa ponsel ketika ada jeda iklan atau saat-saat adegan yang dirasa membosankan. Terakhir, kelima, mudah teralihkan dari percakapan jika mendapat pesan teks atau notifikasi dari media sosial.

Dari hasil identifikasi guru BK SMP Negeri 25 Banjarmasin didapat 30 orang siswa kelas VII yang diidentikasi memenuhi lima kriteria yang dikemukakan oleh Reid. Perlu difahami bahwa Istilah phubbing berasal dari kata "phone" dan "snubbing," yakni menggambarkan tindakan mengabaikan orang lain ketika berinteraksi komunikasi sosial dengan lebih fokus memperhatikan ponsel daripada berbicara dengan orang orang yang dihadapan (Haigh dalam Chotpitayasunondh \& Douglas, 2018, p. 304).

Dalam interaksi sosial, phubber istilah yang diberikan kepada pelaku phubbing dan phubbee adalah istilah bagi korban perilaku phubbing. Phubbing bisa diartikan sebagai individu yang lebih memperhatikan ponselnya saat saat berkomunikasi dengan orang lain dan menghindar dari komunikasi antarpribadi (Karadag et. al, 2015, p. 60).

Selanjutnya, Tim PkM merumuskan materi dan menentukan instrumen pengukuran phubbing dengan memilih menggunakan instrumen Generic Scale of Phubbing (GSP) yang disusun oleh Chotpitayasunondh \& Douglas (2018), mengingat instrumen ini merupakan instrumen sederhana yang bisa mengukur secara praktis .

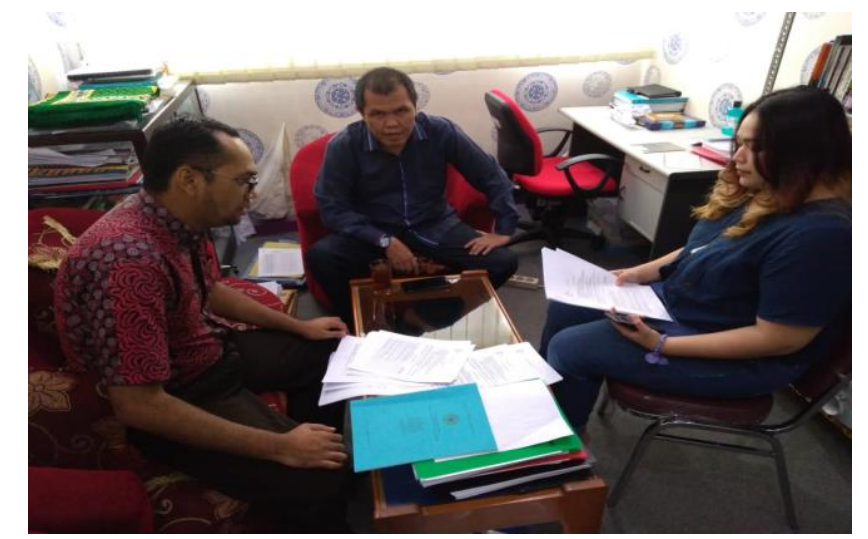

Gambar 1. Tim PkM Mendiskusikan Materi Layanan dan Instrumen GSP

Pada tanggal 19 Juni 2019, dilangsungkan layanan bimbingan klasikal, dengan sebelumnya dilakukan pre-test berdasarkan instrumen GSP hasil yang didapat menunjukkan bahwa siswa yang tergolong memiliki phubbing yang rendah 12 orang, 13 orang dengan ketegori phubbing yang tinggi, dan 5 orang dengan kategori phubbing sangat tinggi. Untuk selanjutnya maka diselenggarakanlah pemberian materi layanan bimbingan klasikal.

\section{Evaluasi Proses Pelaksanaan Layanan}

Evaluasi proses pelaksanaan layanan dimaknai sebagai proses evaluasi yang menitikberatkan evaluasi yang menekankan proses pemberian layanan bimbingan klasikal. Menurut Tim Penyusun Panduan Operasional Penyelenggaraan Bimbingan dan Konseling (2016) disebutkan bahwa evalusi proses layanan sekurang-kurangnya memperhatikan proses yang terjadi berkenaan dengan 4 (empat) hal yakni mengadakan 
refleksi, sikap siswa dalam menngikuti kegiatan, cara siswa menyampaikan pendapat atau bertanya, dan terakhir cara siswa memberikan penjelasan ketika ditanyakan kembali.

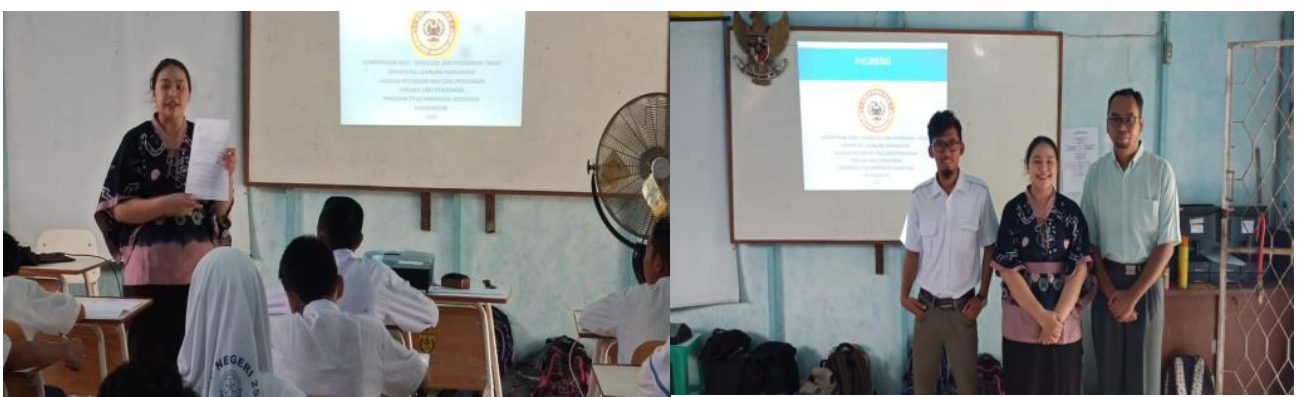

Gambar 2. Berlangsungnya Penyampaian Materi

Dari pelaksanaan pemberian layanan bimbingan klasikal tentang materi phubbing didapat sejumlah hal yang bisa menjadi dasar bagi evaluasi proses yakni sikap antusiasme siswa mengikuti kegiatan pemberian layanan berupa tanggapan spontan dengan penuh semangat terhadap kesempatan yang diberikan oleh tim PkM ketika berlangsungnya proses layanan dan cara siswa yang menjelaskan situasi yang dialaminya ketika mengalami permasalahan akibat perilaku phubbing secara alami dan apa adanya serta kesedian mereka bercerita atas beberapa hal yang mereka alami terkait phubbing yang dibungkus dengan dialog terbuka.

\section{Evaluasi Hasil dari Proses Layanan}

Untuk mengukur evaluasi hasil dari proses layanan bimbingan dampak phubbing, maka Tim PkM kembali lagi membagikan intrumen Generic Scale of Phubbing (GSP) diakhir pelaksanaan layanan bimbingan sebagai post-test akhir. Diharapkan dari hasil post-test tersebut dapat menjadi tolok ukur keberhasilan layanan.

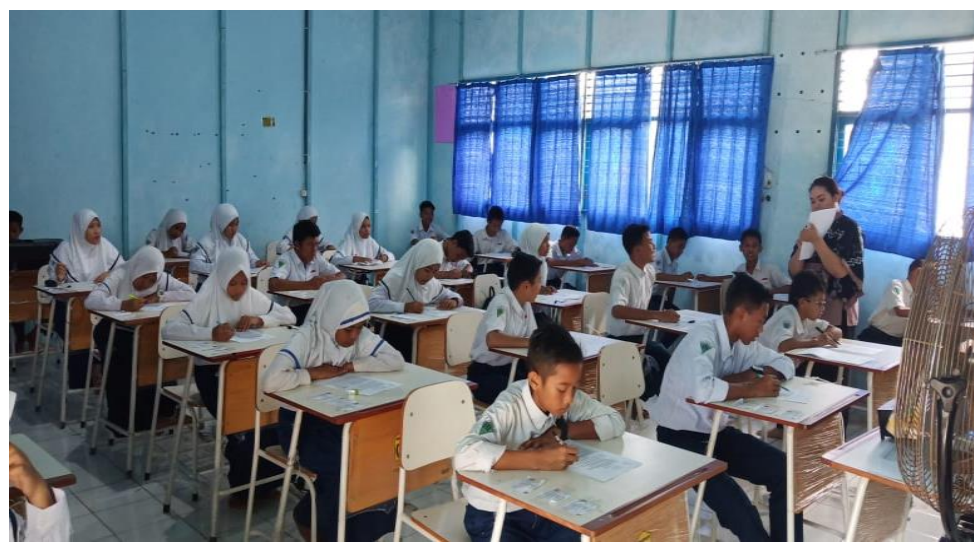

Gambar 3. Siswa Kembali Mengisi Instrumen GSP

Berdasarkan hasil pengukuran instrumen GSP post-test maka didapat hasil data yaitu, siswa yang tergolong memiliki phubbing yang sangat rendah 1 orang, 13 orang dengan kategori phubbing rendah, 14 orang dengan ketegori phubbing yang tinggi, dan 1 orang denga kategori phubbing sangat tinggi. Oleh karena itu, layanan bimbingan klasikal dampak phubbing sebagai gambaran awal berhasil menurunkan jumlah pelaku phubbing. 


\section{SIMPULAN}

Kegiatan layanan bimbingan klasikal ini berhasil mengurangi siswa menjadi pelaku phubbing Walaupun demikian terdapat saran yang dapat dipertimbangkan dari pelaksanaan layanan bimbingan klasikal yakni dari pelaksanaan layanan bimbingan klasikal dapat ditindaklanjuti dalam rencana pemberian jenis layanan konseling kelompok secara intensif dan hasil pelaksanaan pemberian layanan bimbingan klasikal diwancanakan menjadi dasar bagi studi pendahuluan penelitian bertemakan dampak phubbing.

\section{REFERENSI}

Al Subaihi, T. (2017). Phone addiction 'leading to less empathy', US psychologist says. Retrieved October 20, 2018, from https://www.thenational.ae/uae/government/phoneaddiction-leading-to-less-empathy-us-psychologist-says-1.80593\#11

Chotpitayasunondh, V., \& Douglas, K. M. (2018). Measuring phone snubbing behavior: Development and validation of the Generic Scale of Phubbing (GSP) and the Generic Scale of Being Phubbed (GSBP). Computers in Human Behavior, 88, 5-17.

Chotpitayasunondh, V., \& Douglas, K. M. (2018). The effects of "phubbing" on social interaction. Journal of Applied Social Psychology, 48(6), 304-316.

Karadağ, E., Tosuntaş, Ş. B., Erzen, E., Duru, P., Bostan, N., Şahin, B. M., ... \& Babadağ, B. (2015). Determinants of phubbing, which is the sum of many virtual addictions: A structural equation model. Journal of Behavioral Addictions, 4(2), 60-74.

Luik, J. E. (2011). Media sosial dan presentasi diri. In F. Junaedi (Ed.). Komunikasi 2.0: Teoritisasi dan implikasi. Yogyakarta: ASPIKOM bekerja sama dengan Buku Litera.

Ramadhani, M., \& Rezkisari, I. (2016). Tak bisa pisah dengan gadget? hati-hati terkena sindrom phubbing. Retrieved October 20, 2018, from https://www.republika.co.id/berita/gayahidup/info-sehat/16/01/04/o0em1b328-tak-bisa-pisah-dengan-gadget-hatihatiterkena-sindrom-phubbing

Reid, A. J. (2018). The smartphone paradox: our ruinous dependecy in the device age. Conway, USA: Coastal Carolina University.

Tim Penyusun Panduan Operasional Penyelenggaraan Bimbingan dan Konseling. (2016). Panduan operasional penyelenggaraan bimbingan dan konseling Sekolah Menengah Pertama $(S M P)$. Jakarta: Direktorat Jenderal Guru dan Tenaga Kependidikan Kementerian Pendidikan dan Kebudayaan.

Youarti, I. E., \& Hidayah, N. (2018). Perilaku phubbing sebagai karakter remaja generasi Z. Jurnal Fokus Konseling, 4(1), 143-152. 